\title{
Faktor Sumber Daya Manusia dan Komitmen Manajemen yang Mempengaruhi Surveillance Infeksi Nosokomial di Rumah Sakit Paru Batu
}

\section{Human Resource Factors and Management Commitment that Influence Nosocomial Infection Surveillance in Paru Hospital Batu}

\author{
Yuni Kartika $S^{1}$, Tita Hariyant ${ }^{2}$, Lucia Pujiastuti ${ }^{3}$ \\ ${ }^{1}$ Rumah Sakit Lawang Medika Malang \\ ${ }^{2}$ Program Studi Magister manajemen Rumah Sakit Fakultas Kedokteran Universitas Brawijaya Malang \\ ${ }^{3}$ Rumah Sakit Paru Batu
}

\begin{abstract}
ABSTRAK
Surveilans infeksi nosokomial merupakan salah satu kegiatan dalam program Pencegahan dan Pengendalian Infeksi (PPI) di rumah sakit. Studi Pendahuluan menunjukkan angka kejadian plebitis di RS Paru Batu pada tahun 2013 tercatat sebesar 8,23\% dan pada bulan Juni 2014 tercatat sebesar 6,3\%. Kejadian ini cukup tinggi mengingat standar kejadian plebitis yang direkomendasikan oleh standar pelayanan medis minimal tahun 2008 adalah sebesar $\leq 1,5 \%$.. Tujuan dari penelitian ini adalah untuk mengidentifikasi akar permasalahan kurang optimalnya pelaksanaan program pelaporan surveillance infeksi nosocomial di RS Paru Batu. Penelitian dilakukan dengan pendekatan deskriptif kualitatif dengan studi dokumen, wawancara terstruktur dan observasi. Pencarian akar masalah dilakukan dengan melakukan Focus Group Discussion dengan peserta 1 perawat IPCN (Infection Prevention Control Nurse), 8 kepala ruangan rawat inap di RS Paru Batu, koordinator keperawatan dan koordinator pelayanan medis. Hasil penelitian menunjukkan sebagian besar komponen surveilans belum dijalankan dengan benar sesuai Petunjuk Teknis Surveilans dari Kemenkes tahun 2010. Hal tersebut disebabkan kurangnya dukungan manajemen untuk program dan sarana penunjang PPI, belum adanya sosialisasi program kepada seluruh pelaksana surveilans, serta belum adanya fungsi pengawasan terhadap pelaksanaan program surveilans infeksi nosokomial. Hasil tapisan pilihan solusi terbaik dengan skala matriks adalah pengesahan SK pengangkatan Komite dan Tim PPI, menyusun panduan surveilans infeksi nosokomial dan sosialisasi surveilans infeksi nosokomial.
\end{abstract}

Kata Kunci: Angka kejadian plebitis, IPCN, sumberdaya manusia, surveilans infeksi nosokomial

\section{ABSTRACT}

Nosocomial infection surveillance is one of the activities in Infection Prevention and Control program in hospital. Preliminary studies reveal that the incidence of plebitis in Paru Hospital Batu in 2013 was 8,23\% and in June 2014 was recorded at 6,3\%. This incident is quite high considering the standard of plebitis events recommended by minimum standard of medical care in 2008 is $\leq 1,5 \%$. The objective of this study is to identify the problem causing non-optimal program implementation on nosocomial infection surveillance reporting in Paru Hospital Batu. The study was conducted using a qualitative descriptive approach with document examination, structured interviews, and observation. Problem searching was conducted by Focus Group Discussion involving 1 nurse of IPCN (Infection Prevention Control Nurse), 8 coordinators of inpatient wards, coordinators of nursing, and coordinators of medical services. The results showed that most surveillance components have not been carried out properly according to Technical Guidelines on Surveillance of the Ministry of Health in 2010. This situation was due to lack of management support for programs and facilities to support the Infection Prevention and Control program, lack of program socialization to all surveillance personnel, as well as the lack of supervision on the implementation of the nosocomial infection surveillance program. The best solution chosen using matrix scale is validating the decree on appointing the Committee and Team of Infection Prevention and Control program, developing guidelines on nosocomial infection surveillance, and dissemination of nosocomial infection surveillance.

Keywords: Human resources, IPCN, nosocomial infection surveillance, plebitis incidence

Jurnal Kedokteran Brawijaya, Vol. 28, Suplemen No. 2, 2015; Korespondensi: Yuni Kartika S. Rumah Sakit Lawang Medika Malang, JI. DR. Cipt No.8, Lawang-Malang65215 Tel. (0341)420888Email:qiute_niee@yahoo.com 


\section{PENDAHULUAN}

Program pengendalian infeksi nosokomial merupakan salah satu pilar utama mutu layanan kesehatan. Definisi infeksi nosokomial atau yang sekarang disebut sebagai Health-care Associated Infection (HAls) menurut WHO adalah infeksi yang didapatkan dan berkembang selama pasien dirawat di rumah sakit (1). Sumber lain mendefinisikan infeksi nosokomial sebagai infeksi yang terjadi di rumah sakit atau fasilitas pelayanan kesehatan lain setelah dirawat $2 \times 24$ jam (2). Sebelum dirawat, pasien tidak memiliki gejala tersebut dan tidak dalam masa inkubasi. Infeksi nosokomial bukan merupakan dampak dari infeksi penyakit yang telah dideritanya. Pasien, petugas kesehatan, pengunjung, dan penunggu pasien merupakan kelompok yang paling berisiko mendapat infeksi nosokomial, karena infeksi ini dapat menular dari pasien ke petugas, dari pasien ke pasien lain, dari pasien ke pengunjung atau keluarga, ataupun dari petugas ke pasien. Kejadian infeksi nosokomial merupakan masalah besar di negara-negara seperti Jerman, Italia, Inggris dan Amerika Serikat. Studi yang dilakukan oleh WHO pada 55 rumah sakit di 14 negara di seluruh dunia menunjukkan bahwa $8,7 \%$ pasien rumah sakit menderita infeksi selama menjalani perawatan di rumah sakit (2). Bakteremia nosokomial mewakili 5\% proporsi dari infeksi nosokomial keseluruhan namun memiliki case fatality rate tinggi yaitu lebih dari 50\% untuk beberapa organisme (2).

Terapi intravena merupakan aspek penting dalam kegiatan perumahsakitan diantaranya pemberian obat, nutrisi, cairan, produk darah dan untuk memonitor keadaan hemodinamik pasien (3). Plebitis adalah proses peradangan vena dengan penyebab multipel yaitu: trauma (kateter intravena yang terlalu lebar), kimia (misalnya cairan yang mengiritasi vena) dan septik (teknik aseptik yang tidak tepat saat insersi kateter intravena) $(4,5)$. Berdasarkan tinjauan literatur dinyatakan bahwa $5 \%$ sampai $70 \%$ pasien yang mendapat terapi intravena mengalami plebitis (6). Plebitis dikarakteristikkan dengan beberapa manifestasi klinis yaitu pada tempat pemasangan kateter intravena terdapat minimal 2 gejala yang mengikuti yaitu kemerahan, nyeri, bengkak, denyutan vena yang teraba, atau trombosis. Gejala ini berkembang berjam-jam hingga berhari-hari dan membaik dalam beberapa hari hingga beberapa minggu (7).

Angka kejadian plebitis di Indonesia sendiri belum ada angka yang pasti, hal ini kemungkinan disebabkan karena penelitian yang berkaitan dengan insiden kejadian plebitis dan publikasinya masih jarang. Penelitian tentang plebitis yang dipublikasikan di Indonesia antara lain penelitian yang dilakukan Pujasari dan Sumarwati yang meneliti angka kejadian plebitis di sebuah rumah sakit di Jakarta didapatkan kejadian plebitis sebesar $10 \%$ (8). Sementara Gayatri dan Handiyani yang melakukan penelitian di tiga rumah sakit di Jakarta mendapatkan data insiden kejadian plebitis cukup tinggi, yaitu $35,8 \%$ karena pada penelitian tersebut plebitis level I sudah dinyatakan sebagai plebitis (9). Menurut standar pelayanan medis minimal tahun 2008 angka kejadian plebitis yang masih dapat ditolerir adalah sebesar $\leq 1,5 \%$ sedangkan Infusion Nursing Standard of Practice merekomendasikan bahwa level plebitis yang harus dilaporkan adalah level 2 atau lebih. Sedangkan angka kejadian yang direkomendasikan oleh Infusion Nurses Society adalah 5\% atau kurang. Dan jika ditemukan angka kejadian plebitis lebih dari 5\%, maka data harus dianalisis kembali terhadap derajat plebitis dan kemungkinan penyebabnya untuk menyusun pengembangan rencana peningkatan kinerja perawat (10).

Penelitian tentang perilaku pelaporan provider pelayanan kesehatan menunjukkan bahwa kesadaran pelaporan yang rendah merupakan masalah utama dari sistem pelaporan insiden $(11,12)$. Sistem pelaporan secara sukarela diperkirakan sekitar $10 \%$ dari insiden yang terjadi $(13,14)$. Karakteristik individu berpengaruh terhadap kinerja seseorang. Menurut llyas karakteristik individu yang dimaksud adalah usia, jenis kelamin, tingkat pendidikan, dan masa kerja $(15,16)$. Kendala-kendala dalam pelaksanaan tugas dan fungsi panitia pengendalian infeksi di P.K. St. Carolus diantaranya: (a) adanya tugas rangkap, (b) kurangnya pengetahuan pribadi tentang tugas dan wewenang, (c) rendahnya pendidikan, pengetahuan, sikap dan perilaku petugas di lapangan, dan (d) kurangnya referensi (17).

Studi pendahuluan yang dilakukan di Rumah Sakit Paru Batu menunjukkan angka kejadian infeksi nosokomial (plebitis) pada tahun 2013 tercatat sebesar 8,23\% dan pada bulan Juni 2014 tercatat sebesar 6,3\%. Kejadian ini cukup tinggi mengingat standar kejadian plebitis yang direkomendasikan oleh standar pelayanan medis minimal tahun 2008 adalah sebesar $\leq 1,5 \%$. Dari hasil brainstorming dan wawancara yang melibatkan: koordinator pelayanan medik, koordinator keperawatan, 8 kepala ruang, dokter penanggung jawab infeksi nosokomial (inos) dan perawat penanggung jawab infeksi nosokomial (inos) didapatkan adanya gap antara manajemen dan perawat pelaksana terkait kurang optimalnya pelaksanaan program pencegahan dan pengendalian infeksi nosokomial (PPI) pada umumnya dan program pencegahan dan pengendalian plebitis khususnya di RS Paru Batu. Tujuan dari penelitian ini adalah untuk menganalisis faktor-faktor yang mempengaruhi pelaksanaan surveilans infeksi nosokomial, memberikan alternatif solusi terhadap akar permasalahan tersebut dan memberikan rekomendasi kepada pihak rumah sakit. Penelitian ini diharapkan dapat membantu terselenggaranya kegiatan surveilans infeksi nosokomial secara efektif sesuai pedoman dalam Petunjuk Praktis Surveilans Infeksi Nosokomial dari Depkes tahun 2010 untuk mengurangi angka kematian dan angka kejadian infeksi nosokomial di RS Paru Batu.

\section{METODE}

Penelitian ini merupakan penelitian kualitatif yang dilakukan untuk mengamati proses kegiatan surveilans di ruang rawat inap dalam hal pengumpulan data sampai evaluasinya. Metode yang digunakan dengan observasi dan wawancara terhadap pelaksana surveilans di ruang rawat inap, pengelolaan dan analisis data di unit Rekam Medik. Wawancara terstruktur dengan ketua komite PPI, 1 orang IPCN (Infection Prevention and Control Nurse), dan 8 orang kepala ruang terkait sistem monitoring dan evaluasi pelaporan plebitis, sistem remunerasi dari pelaporan plebitis pada khususnya dan infeksi nosokomial pada umumnya, serta pengadaan fasilitas hand hygiene dan alat pelindung diri dalam melakukan pelayanan kepada pasien. Untuk mencari akar penyebab masalah dilakukan melalui brainstorming pada September 2014 dengan peserta 1 orang perawat IPCN, 8 orang kepala ruang, koordinator keperawatan dan koordinator pelayanan medis dengan 
alat bantu diagram Fishbone. Tehnik penentuan prioritas akar permasalahan yaitu dengan menggunakan metode Reinke yang merupakan metode dengan mempergunakan skor 1-5 yang meliputi komponen: magnitude of problem (besarnya masalah), importancy (kegawatan masalah), vulnerability (sensitif atau tidaknya pemecahan masalah dalam pemecahan masalah), dan cost (biaya atau dana yang dipergunakan untuk pemecahan masalah tersebut), kemudian ditapis lagi dengan kriteria matriks untuk mencari solusi terbaik.

Penilaian matriks kriteria yang digunakan meliputi: a. efektifitas, yang menunjukkan pengaruh yang ditimbulkan oleh tindakan pemecahan masalah, b. ketersediaan dana, yang menunjukkan murah atau mahalnya pemecahan masalah dilakukan, c. Ketersediaan barang (sarana penunjang), yang menunjukkan mudah atau tidaknya pemecahan masalah dilakukan, d. Ketersediaan SDM, yang menunjukkan kemampuan sumber daya manusia untuk melakukan pemecahan masalah. Pada masingmasing kriteria penilaian diberikan skor 1 sampai dengan 5, dengan interpretasi sebagai berikut: Skor 1: sangat tidak efektif/sangat tidak murah/sangat tidak mudah/sangat tidak mampu, skor 2: tidak efektif/tidak murah/tidak mudah/tidak mampu, skor 3: cukup efektif/cukup murah/cukup mudah/cukup mampu, skor 4: efektif/murah/mudah/mampu, skor 5: sangat efektif/sangat murah/sangat mudah/sangat mampu.

\section{HASIL}

Dalam rangka mengidentifikasi akar permasalahan pelaksanaan surveilans infeksi nosokomial yang belum sesuai standar tersebut maka dilakukan brainstroming yang melibatkan koordinator pelayanan medik, komite keperawatan, Tim PPI, dan beberapa kepala ruangan rawat inap RS Paru Batu. Dalam brainstorming tersebut peserta didorong untuk mengungkapkan permasalahanpermasalahan yang dihadapi terkait pelaksanaan surveilans infeksi nosokomial, dimana permasalahanpermasalahan tersebut dapat dikelompokkan menjadi 5 aspek yaitu berdasarkan: sumber daya manusia (man), metode (methode), lingkungan (environment), sumber daya barang (material), dan manajemen (management). Dari ke lima aspek tersebut kemudian disajikan dalam bentuk diagram fish-bone Ishikawa (Gambar 1).

Setelah membentuk diagram fishbone tersebut kemudian dilanjutkan dengan membuat prioritas permasalahan. Dalam hal ini dilakukan pembatasan hanya tiga akar masalah utama yang akan dikaji dan akan diberikan rekomendasi pemecahan masalahnya. Untuk memprioritaskan akar masalah ini, digunakan metode Reinke yang merupakan metode dengan mempergunakan skor 1 -5 yang meliputi komponen: Magnitude of problem (besarnya masalah), importancy (kegawatan masalah), vulnerability (sensitif atau tidaknya pemecahan masalah dalam pemecahan masalah), dan cost (biaya atau dana yang dipergunakan untuk pemecahan masalah tersebut). Dari metode Reinke tersebut didapatkan 3 prioritas permasalahan sebagai berikut: (a) kurangnya kesadaran dan pemahaman staf terhadap surveilans infeksi nosokomial di RS Paru Batu; (b) Belum adanya panduan pelaksanaan surveilans infeksi nosokomial dan sosialisasinya kepada seluruh staf dan (c) SK (Surat Keputusan) pengangkatan Komite PPI dan Tim PPI yang belum dilengkapi dengan tupoksi yang jelas.

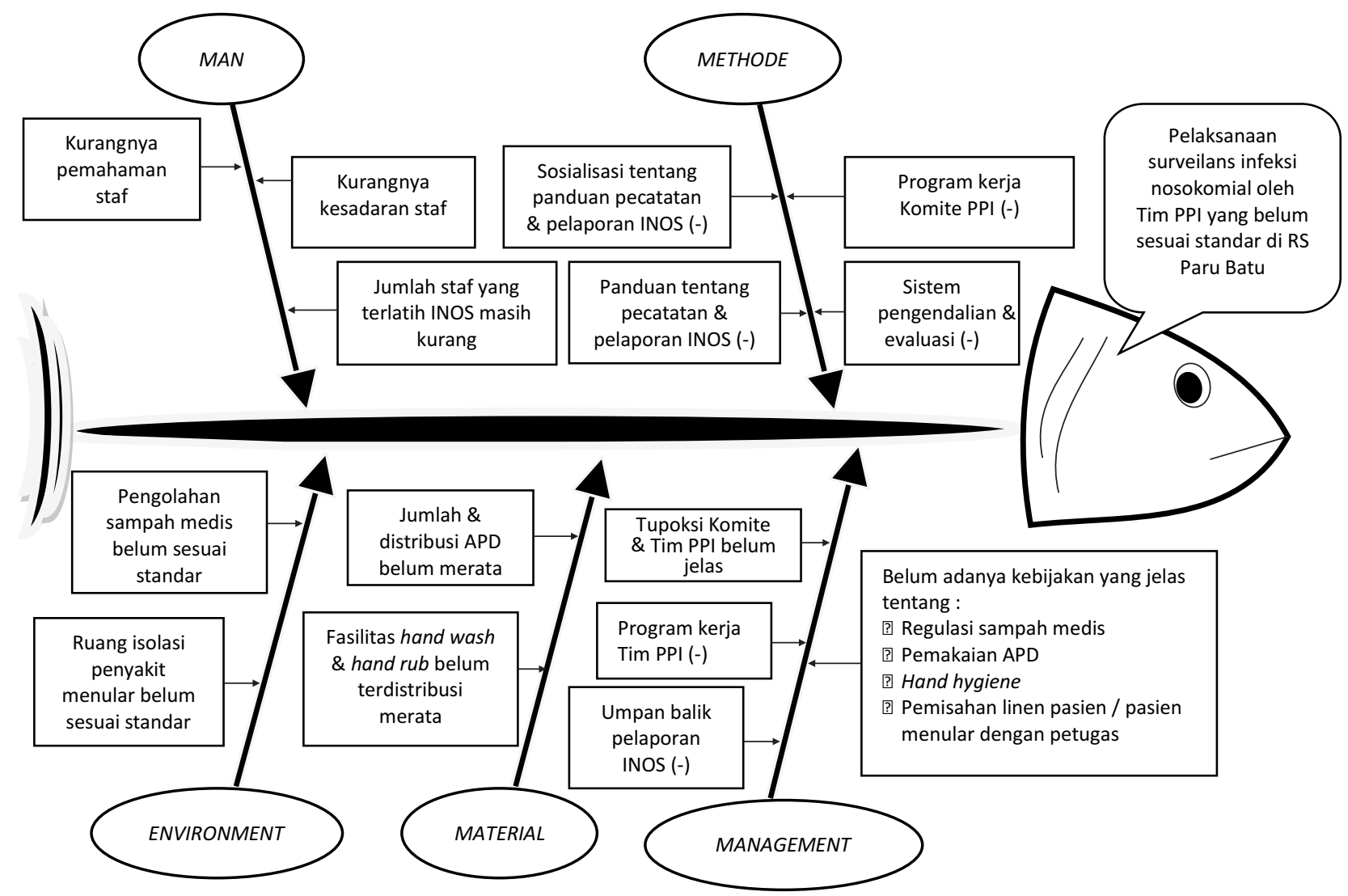

Gambar 1. Diagram fishbone pelaksanaan surveilans infeksi nosokomial oleh tim PPI yang belum sesuai standar di RS Paru Batu 
Tabel 1. Alternatif solusi

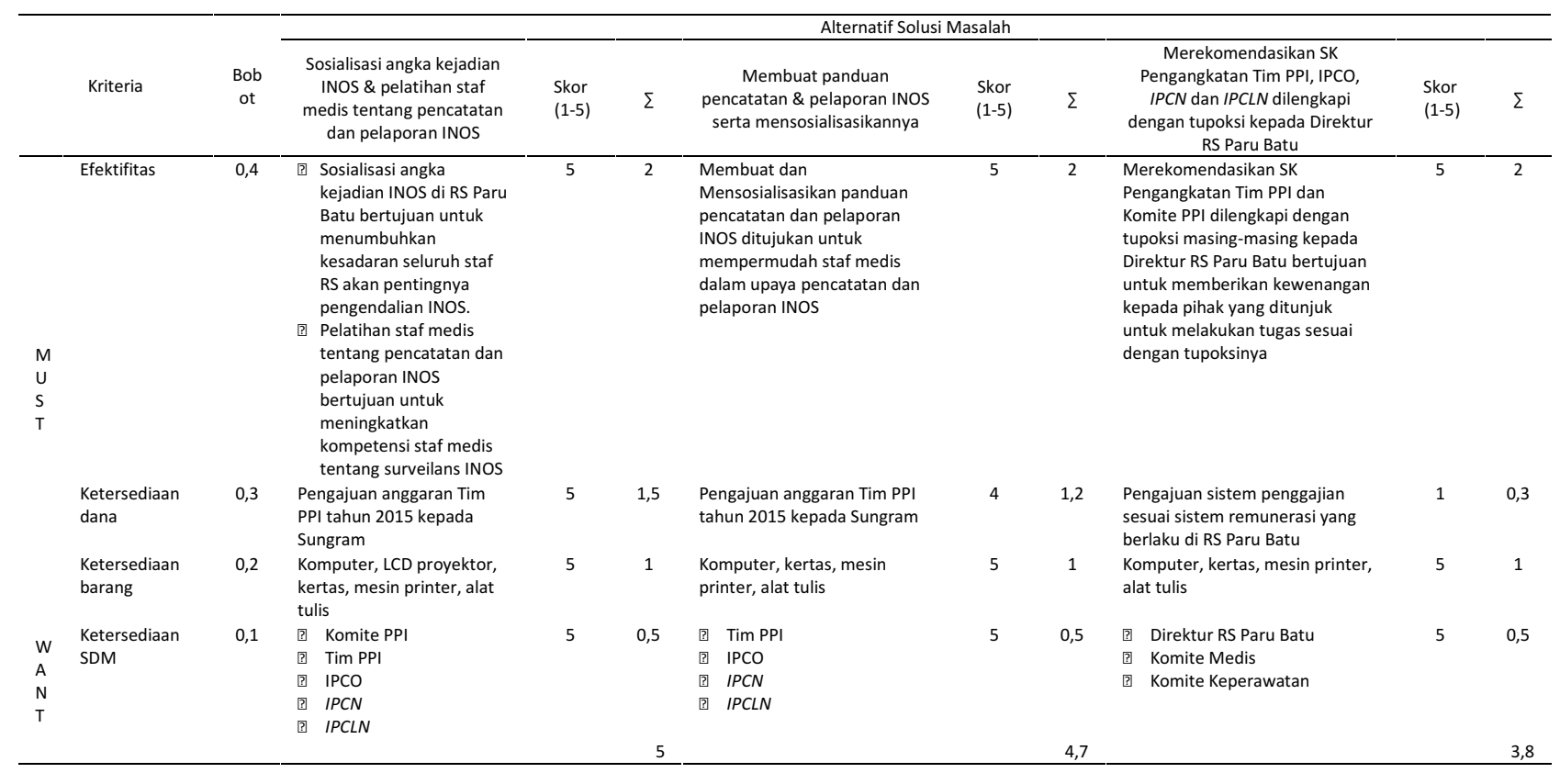

Ketiga prioritas permasalahan tersebut kemudian dilanjutkan dengan pembobotan melalui kriteria matriks untuk menentukan prioritas pemecahan masalah. Hasil dari Penilaian kriteria matriks adalah sebagai berikut:

Dari kriteria matriks tersebut, dihasilkan beberapa rekomendasi sebagai berikut: (a) Sosialisasi surveilans infeksi nosokomial terhadap seluruh staf RS Paru Batu; (b) Rekomendasi SK (Surat Keputusan) Pengangkatan Komite PPI dan Tim PPI RS Paru Batu; dan (c) Penyusunan Pedoman Surveilans Infeksi Nosokomial RS Paru Batu.

\section{DISKUSI}

Berdasarkan hasil studi pendahuluan, wawancara dan brainstorming dengan 1 perawat IPCN (Infection Prevention Control Nurse), 8 kepala ruangan rawat inap di RS Paru Batu, koordinator keperawatan dan koordinator pelayanan medis ditemukan beberapa akar permasalahan terkait pelaksanaan surveilans infeksi nosokomial yang saat ini dihadapi oleh RS Paru Batu. Beberapa permasalahan tersebut dapat dikelompokkan menjadi dua kelompok permasalahan yaitu: pertama: kurangnya dukungan dan komitmen manajemen terhadap program pengendalian dan pencegahan infeksi nosokomial, dan kedua: beberapa permasalahan lain terkait sumber daya manusia. Salah satu penelitian yang mengkaji faktorfaktor yang mempengaruhi klinisi dalam melakukan pelaporan berdasarkan teori tindakan beralasan yaitu penelitian yang dilakukan oleh Pfeiffer et al. Penelitian tersebut mengelompokkan 3 faktor yang mempengaruhi klinisi dalam melakukan pelaporan yaitu: faktor individu, faktor organisasi, dan persepsi dari sistem pelaporan tersebut (10).

Beberapa permasalahan terkait kurangnya dukungan dan komitmen manajemen terhadap program pengendalian dan pencegahan infeksi nosokomial diantaranya sebagai berikut: (a) belum disahkannya SK Pengangangkatan Komite PPI dan Tim PPI oleh direktur RS sehingga dalam kesehariannya tugas dan tanggung jawab yang diberikan belum dilaksanakan secara optimal, (b) belum adanya pengalokasian dana kepada program PPI sehingga Tim PPI yang sudah terbentuk banyak menghadapi kendala dalam pelaksanaan program kerjanya terkait pengembangan pengetahuan SDM serta pengadaan sarana dan prasarana yang menunjang program PPI, (c) belum adanya monitoring dan evaluasi secara berkala terhadap program PPI di rumah sakit dan (d) belum adanya umpan balik dari manajemen terkait pelaporan kejadian infeksi nosokomial yang sudah dilakukan. Bentuk kebijakan manajemen/ direktur rumah sakit adalah membentuk Komite PPI dan Tim PPI yang langsung berada dibawah koordinasi Direktur. Komite dan Tim PPI mempunyai tugas, fungsi, kewenangan yang jelas sesuai dengan Pedoman Manajerial Pencegahan dan Pengendalian Infeksi di Rumah Sakit dan Fasilitas Kesehatan Lainnya Tahun 2008 (1). Menurut Swanborg pada tahun 2000 dalam penelitian Molina pada tahun 2012, menyatakan bahwa salah satu fungsi manajemen adalah memimpin sebagai proses pendelegasian, pengawasan, koordinasi dan pengendalian implementasi rencana organisasi. Fokus dari fungsi manajemen adalah membimbing dan meningkatkan motivasi dengan upaya yang dilakukan yaitu: membuat sistem penghargaan, memberikan umpan balik positif, mengintegrasikan tujuan organisasi dengan staf/individu, mengurangi ketidakpuasan kerja, mendukung sumber daya (sumber daya manusia, persediaan dan perlengkapan, program Diklat, dan sebagainya) (11). Penelitian lain juga menyebutkan bahwa dua dari tiga responden meyakini bahwa kurangnya umpan balik dari manajemen merupakan hal terbesar yang membuat petugas kesehatan jera dalam melakukan pelaporan. Faktor-faktor organisasi berhubungan dengan struktur dan proses dalam pelaporan, misalnya: umpan balik yang tidak memadai, bentuk pelaporan yang panjang, dan tidak cukup waktu untuk melaporkan diidentifikasi sebagai penghalang utama dari sistem pelaporan (12).

Beberapa permasalahan lain terkait sumber daya manusia yang menyebabkan penurunan pelaporan plebitis di RS Paru Batu yaitu: (a) Kurangnya jumlah tenaga PPI yang terlatih, (b) Kurangnya kesadaran dan pemahaman staf akan pentingnya program surveilans infeksi nosokomial, dan (c) Tenaga IPCN yang belum purna waktu. Jumlah tenaga PPI yang terlatih di RS Paru Batu yaitu sebanyak 
empat orang, dimana ke empat tenaga tersebut mendapatkan pelatihan tentang surveilans PPI pada saat awal dibentuk Tim PPI pada tahun 2010 dalam rangka persiapan akreditasi rumah sakit, selanjutnya belum diadakan kembali. Penelitian tentang perilaku pelaporan provider pelayanan kesehatan menunjukkan bahwa kesadaran pelaporan yang rendah merupakan masalah utama dari sistem pelaporan insiden (13) (14). Pelaporan secara sukarela diperkirakan sekitar $10 \%$ dari insiden yang terjadi $(15,16)$.

Permasalahan yang sama juga ditemukan dari penelitian Permana dan Adisasmito tentang pelaksanaan Tim PPI rumah sakit di Pelayanan Kesehatan St. Carolus Jakarta. Rendahnya pengetahuan pelaksana harian tentang pengendalian infeksi nosokomial khususnya surveilans dapat menyebabkan tidak terlaksananya surveilans di unit-unit perawatan secara baik. Pelaksanaan surveilans yang tidak memenuhi persyaratan akan memunculkan angka infeksi nosokomial yang dapat diragukan kebenarannya. Seluruh informan (IPCN dan11 IPCLN) pada penelitian tersebut sependapat bahwa mereka mengalami kendala dalam pelaksanaan tugas dan fungsinya dalam Panitia Pengendalian Infeksi karena: mempunyai tugas rangkap; kurangnya pengetahuan

\section{DAFTAR PUSTAKA}

1. Departemen Kesehatan Republik Indonesia. Pedoman Manajerial Pencegahan dan Pengendalian Infeksi di Rumah Sakit dan Fasilitas Pelayanan Kesehatan Lainnya. Jakarta: Departemen Kesehatan $\mathrm{Rl} ; 2008$.

2. Nejad SB, Allegranzi B, Syed SB, Ellisc B, and Pittetd D. Health-care-associated Infection in Africa: $A$ Systematic Review. Bulletin of the World Health Organization. 2011; 89: 757-765.

3. O'Grady NP, Alexander M, Burns LA, et al. Guidelines for the Prevention of Intravascular Catheter-Related I n fections. (O n I i n e ) 2011 . http://www.cdc.gov/hicpac/BSI/BSI-guidelines2011.html.

4. Clayton BD and Stock YN. Pharmacology in Nursing Practice. In: Clayton BD and Willihnganz M (Eds). Basic Pharmacology for Nurses 13th edition. Missouri: Elsevier; 2010.

5. Rivas DJS, Artes LJL, Arjona BJ, et al. How to Reduce the Incidence of Traumatic Phlebitis. Revista LatinoAmericana de Enfermagem 2004; 27(9): 42-46.

6. Kaur P, Thakur R, Kaur S, and Bhalla A. Assesment of Risk Factors of Phlebitis Amongst Intravenous Cannulated Patient. Nursing and Midwifery Research Journal. 2011; 7(3): 106-114.

7. Alexander M, Corrigan A, Gorski L, Hankins J, and Peruca R. Infusion Nursing Society. Infusion Nursing: An Evidence-Based Approach. Third Edition. Philadelphia: Saunders Elsevier; 2000.

8. Pujasari H and Sumarwati, M. Angka Kejadian Flebitis dan Tingkat Keparahannya di Ruang Penyakit Dalam di Sebuah Rumah Sakit di Jakarta. Jurnal Keperawatan Indonesia. 2002; 6(1): 1-5.

9. Gayatri D and Handayani H. Hubungan Jarak Pemasangan Terapi Intravena dari Persendian pribadi tentang tugas dan wewenang; rendahnya pendidikan, pengetahuan, sikap dan perilaku petugas di lapangan serta kurangnya referensi tentang surveilans infeksi nosokomial (17).

Kinerja surveilans infeksi nosokomial di RS Paru Batu yang belum sesuai standar disebabkan karena kurangnya dukungan dan komitmen manajemen dan beberapa permasalahan lain terkait sumber daya manusia. Demi terlaksananya program pencegahan dan pengendalian infeksi nosokomial di RS Paru Batu, dibutuhkan dukungan dan komitmen manajemen rumah sakit diantaranya dalam hal: (a) pengesahan SK Pengangkatan Komite dan Tim PPI yang dilengkapi dengan uraian tugasnya masing-masing, (b) mengangkat tenaga perawat purna waktu yang sudah terlatih program PPI sebagai IPCN, (c) adanya monitoring dan evaluasi secara berkala antara komite PPI, Tim PPI dan manajemen rumah sakit, dan (d) adanya pengalokasian dana terkait pelaksanaan program PPI. Selain itu untuk meningkatkan kinerja staf dalam pelaksanaan program surveilans infeksi nosokomial perlu adanya: (a) sosialisasi program PPI RS Paru Batu, (b) pelatihan surveilans PPI bagi tenaga PPI yang belum terlatih, (c) membuat panduan sistem pencatatan dan pelaporan infeksi nosokomial.

terhadap Waktu Terjadinya Plebitis. Jurnal Keperawatan Indonesia. 2007; 11(1): 1-5.

10. Pfeiffer $\mathrm{Y}$, Manser $\mathrm{T}$, and Wehner T. Conceptualising Barriers to Incident Reporting: A Psychological Framework. Quality \& Safety in Health Care. 2010; 19(6): e60.

11. Swansburg RC. Nursing Staff Development: $A$ Component of Human Resource Development (Jones and Barlett Series in Nursing). 1st edition. Burlington: Jones \& Barlett Publiser; 1995.

12. Evans SM, Berry JG, Esterman AJ, et al. Attitude and Barriers to Incident Reporting: A Collaborative Hospital Study. Quality \& Safety in Health Care. 2006; 15(1): 39-43.

13. Stanhope N, Crowley-Murphy M, Vincent C, O'Connor AM, and Taylor-Adams SE. An Evaluation of Adverse Incident Reporting. Journal of Evaluation in Clinical Practice. 1999; 5(1): 5-12.

14. Schuerer DJ, Nast PA, Harris CB, et al. A New Safety Event Reporting System Improves Physician Reporting in the Surgical Intensive Care Unit. Journal of the American College of Surgeons 2006; 202(6): 881-887.

15. Jones KJ, Cochran GL, Hicks RW, and Mueller KJ. Translating Research into Practice: Voluntary Reporting of Medication Errors in Critical Access Hospitals. The Journal of Rural Health's. 2004; 20(4): 335-343.

16. Barach $\mathrm{P}$ and Small SD. Reporting and Preventing Medical Mishaps: Lessons from Non Medical Near Miss Reporting Systems. British Medical Journal. 2000: 320(7237): 759-763.

17. Pernnanal LW dan Adisasmito W. Analisis Pelaksanaan Tugas dan Fungsi Panitia Pengendalian Infeksi Nosokomial Pelayanan Kesehatan St. Carolus Jakarta Tahun 2004. Jurnal Manajemen Pelayanan Kesehatan. 2005; 8(2): 99-104. 